\title{
Ellipsis
}

2015

\section{Security Levels}

Eric G. Hollerbach

University of New Orleans

Follow this and additional works at: https://scholarworks.uno.edu/ellipsis

\section{Recommended Citation}

Hollerbach, Eric G. (2015) "Security Levels," Ellipsis: Vol. 42 , Article 7.

DOI: https://doi.org/10.46428/ejail.42.07

Available at: https://scholarworks.uno.edu/ellipsis/vol42/iss1/7

This Poetry is brought to you for free and open access by the Department of English and Foreign Languages at ScholarWorks@UNO. It has been accepted for inclusion in Ellipsis by an authorized editor of ScholarWorks@UNO.

For more information, please contact scholarworks@uno.edu. 


\title{
Security Levels
}

\author{
Eric Hollerbach
}

Let those so corrupt see

Bring me your most cruel

Your sociopaths.

What is so beyond reproach

That the disinfecting rays of the

Sun, dare not shine?

The more secure

The more blatantly illegal

Depraved and unconstitutional.

Until leaked into public laws

Slowly, scientifically

As a snake constricts wriggling prey.

Information leaks as slowly

As holes in the heads of

Whistleblowers.

Continuity of government

Underground bases to hoard the

Perpetrators.

This is on a strictly

Need to know basis. 